\title{
MENGUKUR HASIL BELAJAR EKONOMI MENGGUNAKAN MEDIA ASESMEN WORD SEARCH PUZZLE DI PLATFORM ANDROID
}

\author{
Siti Mujaiyanah \\ Universitas Negeri Surabaya \\ Email: sitimujayanah50@gmail.com
}

\begin{abstract}
Abstrack
The assessment media is used as a benchmark for students ability after pasticipating in learning, but if the assessment process is carried out using irrelevant media, he objectives of learning can not be achieved. This study aims to describe the feasinility, practicality, and effectiviness of the use of the Word Search Puzzle assessment media on the android platform. The research type is research and development (R\&D) with ADDIE models from Dick and Carry which has 5 stages: Analysis, Design, Development, Implementation, and Evaluation. The research trial design using the One Group Pretest Posttest Design, Validity product instrument were obtained from assessment expert, liguists, media expert, and student responses. The result showed that: (1) the development of the Word Search Puzzle assessment media is feasible, based on validation result with an average percentage of 75,93\%; (2) Word Search Puzzle media is considered practical in learning because it is able to increase the interest of students, based on the students responses that get an average percentage of $88,92 \%$; and (3) the Word Search Puzzle assessment media is affective to measure with the final result being $100 \%$ passed through classical completeness.
\end{abstract}

Keywords: Word Search Puzzle, Assessment media, Learning outcomes

\section{Pendahuluan}

Pendidikan ialah usaha yang dilaksanakan secara sadar dan terprogram agar peserta didik mempunyai suasana dan pengalaman belajar yang baik, sehingga membuat peserta didik mampu berkontribusi secara bermakna kepada masyarakat (Raharjo, 2010). Dalam setiap akhir proses pembelajaran tentu dibutuhkan asesmen untuk mengetahui prestasi belajar peserta didik.

Pada zaman sekarang ilmu pengetahuan dan teknologi berkembang pesat sehingga menyebabkan terjadinya pembaruan-pembaruan di berbagai macam bidang termasuk pada bidang pendidikan yang mengalami pembaruan. Salah satu pembaruan pada bidang pendidikan adalah dengan memanfaatkan teknologi untuk menunjang kegiatan belajar mengajar. Teknologi dapat mempermudah proses berjalannya pembelajaran di masa kini maupun di masa yang akan datang. Pembaruan bidang pendidikan salah satunya terlihat pada pemanfaatan media audio visual, multimedia, dan media proyeksi sebagai media asesmen.

Pendidik dapat menggunakan media asesmen yang mengharuskan peserta didik ikut berperan aktif dalam pembelajaran, karena kini pendidik bukan lagi pusat pembelajaran melainkan peserta didik harus ikut aktif dalam pembelajaran. Media asesmen dapat digunakan untuk meningkatkan sarana kegiatan belajar yang memiliki tujuan meningkatkan mutu pendidikan dan hasil belajar peserta didik, selanjutnya hasil proses asesmen digunakan sebagai tolok ukur keberhasilan proses pembelajaran (Purwati \& Nugroho, 2018).

Berdasarkan hasil pengamatan di kelas X IPS SMA Labschool UNESA, pendidik sudah memanfaatkan media dalam proses pembelajaran dengan maksimal, sehingga pada materi ekonomi yang disampaikan dapat diterima dengan baik oleh peserta didik. Namun pendidik hanya memanfaatkan media dalam proses pembelajaran saja, pada saat proses asesmen pendidik hanya memberikan soal diatas kertas yang dapat menyebabkan peserta didik kurang tertarik dan merasa tegang saat melaksanakan asesmen. Hal ini dapat menyebabkan perolehan nilai peserta didik lebih rendah dari Ketuntasan Belajar Minimal (KBM) dan juga dari 28

DOI: 10.33603/ejpe.v8i2.3669

This is an open access article under the CC-BY-SA license 
peserta didik terdapat 22 peserta didik yang lebih senang bermain game apabila diberikan soal yang tidak menarik akan menyebabkan peserta didik malas dalam menyelesaikan soal yang diberikan.

Media ialah semua yang dapat digunakan oleh pendidik sebagai penyalur informasi ataupun menyajikan informasi kepada peserta didik (Nurseto, 2011). Asesmen adalah sistem multimetode dan multidimensi yang dapat digunakan oleh pendidik untuk mengevaluasi perilaku dan persepsi diri. Secara multidimensi dapat digunakan oleh segala usia dari anak sampai dewasa, sedangkan secara multimetode karena memiliki komponen secara individual ataupun kombinasi (Salkind, 2013). Permainan merupakan situasi bermain yang memiliki aturan dan tujuan yang menghasilkan tindakan yang dapat dilakukan secara individu maupun kelompok (Yumarlin, 2013).

Melihat fenomena yang terjadi di kelas X IPS SMA Labschool UNESA, peneliti tertarik untuk membuat media asesmen Word Search Puzzle dengan menggabungkan game pada kegiatan asesmen sehingga dapat mengurangi rasa tegang dan membuat proses asesmen lebih menarik peserta didik karena pelaksanaan proses asesmen yang menyenangkan. Word Search Puzzle yang digunakan untuk media asesmen berupa permainan dalam bentuk game aplikasi yang dapat dimanfaatkan dengan menyusun kata yang dicari pada potonganpotongan huruf yang telah disediakan. Rahmah (2016) dalam penelitiannya dengan menggunakan Word Search Puzzle dapat meningkatkan pengguasaan kosakata tanpa harus dipaksa untuk menghafal. Selanjutnya Chesy (2018) dalam penelitiannya Word Search Puzzle dapat meningkatkan prestasi belajar dalam kelas, dan dalam penelitian Saidah (2015) disimpulkan bahwa Word Search Puzzle dapat digunakan secara perorangan maupun dalam uji coba lapangan.

Word Search Puzzle ialah permainan pencarian kata dalam bentuk teka-teki yang terdiri dari potongan-potongan huruf yang telah diacak, dimana kata-kata telah dieja secara horizontal, vertikal, maupun diagonal (Mailawati, 2019). Aplikasi merupakan program yang dapat digunakan seseorang untuk menjalankan suatu sistem operasi pada gawai yang disebut dengan android (Aminudin et al., 2018). Android adalah sumber terbuka untuk seluruh aplikasi dari modul linux tingkat rendah sampai perpustakaan aplikasi tingkat tinggi (Gargenta, 2011).

Media asesmen Word Search Puzzle dipilih karena sesuai dengan hasil observasi yang menunjukkan bahwa peserta didik membutuhkan media asesmen yang menggabungkan permainan dengan proses asesmen agar tidak merasa tegang saat melaksanakan proses asesmen. Penelitian Ratnaningsih (2010) dengan menggunakan media evaluasi Word Search Puzzle dapat membuat hasil belajar peserta didik mengalami peningkatan dan dapat memperkaya kosa kata biologi dengan menggunakan media evaluasi tersebut. Hermawaty, Krisdiawan, \& Nurhayati (2019) menyimpulkan dalam penelitiannya bahwa penggunaan memori pada aplikasi game Word Search Puzzle akan semakin besar apabila mencari kata pada permainan semakin lama, sehingga akan menantang peserta didik untuk semakin cepat menyelesaikan permainan.

Tarigas (2014) menyatakan bahwa media evaluasi Word Search Puzzle dapat meningkatkan keterampilan motorik, melatih kebutuhan emosional dan melatih kecerdasan peserta didik yang berpengaruh pada prestasi belajar peserta didik. Selanjutnya penelitian yang dilaksanakan Chin, Payne, Fu, Morrow, \& Stine-Morrow (2015) dengan menggunakan Word Search Puzzle dapat mengetahui perbedaan usia dengan melihat tingkat perolehan informasi. 
Karena adanya keselarasan media asesmen dengan keperluan peserta didik maka dapat mempengaruhi hasil belajar peserta didik. Asesmen ialah proses pemberian nilai kepada peserta didik setelah proses belajar selesai yang digunakan untuk penilaian proses dan melihat kemajuan belajar peserta didik (Wulan, 2010). Indikator hasil belajar yang digunakan dalam pengembangan ini yakni nilai yang diperoleh peserta didik dengan menggunakan media asesmen Word Search Puzzle sudah memenuhi KBM yang ditentukan oleh sekolah.

Tujuan dilakukan penelitian adalah: (1) mendeskripsikan tingkat kelayakan media asesmen; (2) mendeskripsikan kepraktisan penggunaan media asesmen; dan (3) mendeskripsikan efektifitas penggunaan media asesmen Word Search Puzzle di platform android pada mata pelajaran Ekonomi kelas X IPS di SMA Labschool UNESA.

\section{Metode Penelitian}

Penelitian ini memakai metode penelitian dan pengembangan (Research and Development R\&D) pada produk bidang pendidikan, dengan mengadaptasi model pengembangan ADDIE dari Dick dan Carry yang terdapat lima tahapan, yakni: Analysis, Design, Development, Implementation, dan Evaluation (Sani, Manurung, Suswanto, \& Sudiran, 2018). Prosedur penelitian, sebagai berikut:

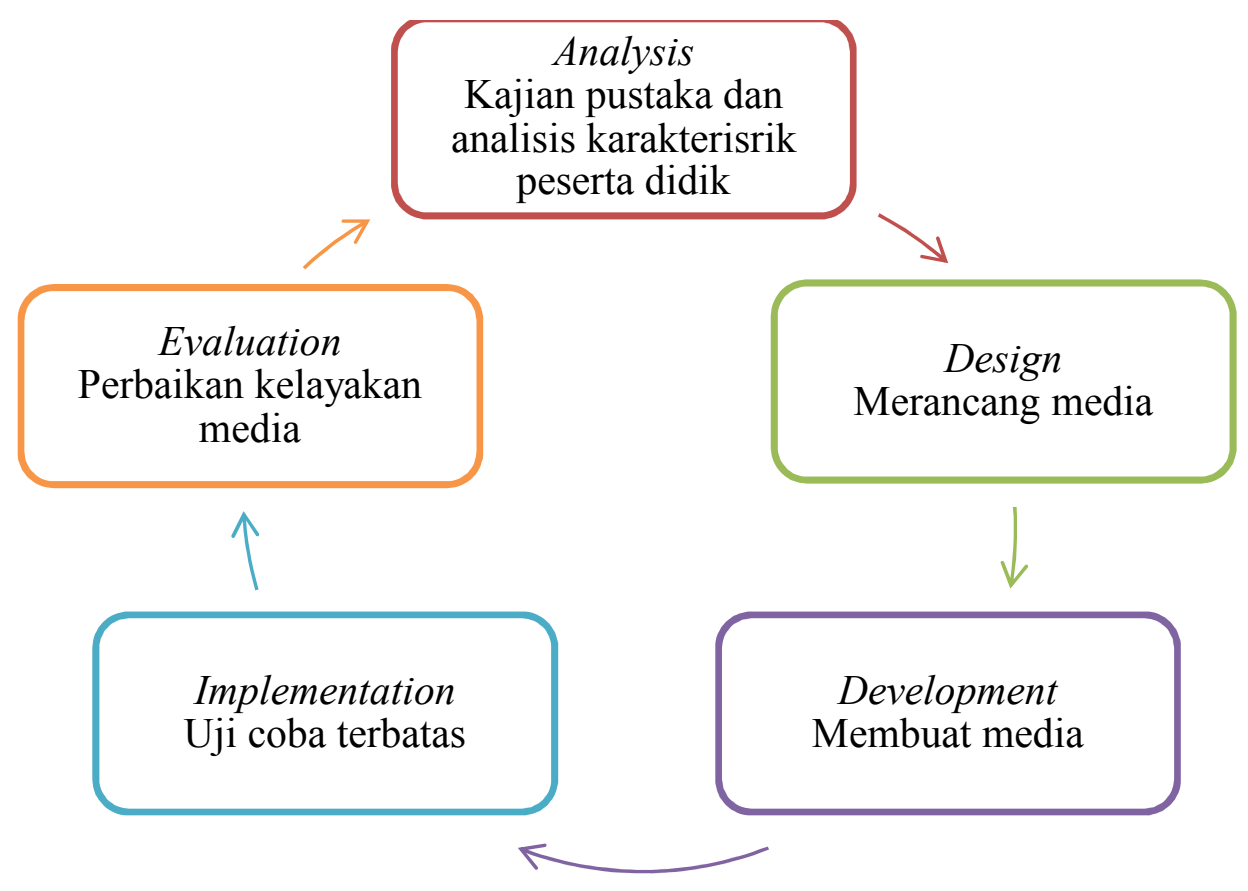

Gambar 1. Prosedur Pengembangan yang dimodifikasi dari model ADDIE Dick dan Carry Sumber: Mahendra (2016)

Terdapat rincian tahapan model ADDIE dalam melakukan penelitian dan pengembangan: (1) analisis (Analysis), mengumpulkan informasi awal dengan melakukan kajian pustaka, pengamatan kelas, dan pengamatan tugas peserta didik kelas X IPS 2 SMA Labschool UNESA; (2) perancangan (Design), pada proses perancangan peneliti menentukan instrumen yang menunjukkan kelayakan media, kepraktisan media, dan keefektifan media; (3) pengembangan (Development), tahap pengembangan dilaksanakan dengan memproduksi 
produk yang telah direncanakan, setelah produk selesai dibuat berikutnya dilaksanakan proses telaah dan validasi oleh ahli asesmen, ahli bahasa, dan ahli media; (4) uji coba (Implementation), uji coba terbatas dilaksanakan kepada peserta didik kelas X IPS di SMA Labschool UNESA, dan (5) Evaluasi (Evaluation), perbaikan produk dilaksanakan sesuai dengan kritik, saran, dan masukan yang diperoleh dari ahli asesmen, ahli bahasa, dan ahli media pada tahap pengembangan.

Desain uji coba pengembangan media asesmen Word Search Puzzle di platform android ini menggunakan One Group Pretest Posttest Design, berikut desain uji coba:

$$
\mathrm{O}_{1} \rightarrow \mathrm{X} \rightarrow \mathrm{O}_{2}
$$

Gambar 2. Desain Uji Coba

Sumber: Sugiyono (2018)

Keterangan:

$\mathrm{O}_{1}=$ Nilai Pretest

$\mathrm{X}=$ Pembelajaran

$\mathrm{O}_{2}=$ Nilai Posttest

Peserta didik kelas X IPS SMA Labschool UNESA adalah populasi dalam penelitian ini dengan jumlah 54 peserta didik. Dengan mengambil subjek uji coba kelas X IPS 2 yang berjumlah 28 peserta didik untuk melaksanakan pengukuran hasil belajar sebelum pembelajaran dengan menggunakan media kertas dan setelah pembelajaran berakhir dengan menggunakan media asesmen Word Search Puzzle di platform android. Pelaku yang terlibat dalam penelitian ini yakni dosen ahli asesmen, dosen ahli bahasa, dosen ahli media, pendidik mata pelajaran Ekonomi, dan peserta didik yang akan melaksanakan uji coba dari media asesmen Word Search Puzzle di platform android.

Teknik pengumpulan data dalam penelitian ini dengan menggunakan instrument telaah ahli, instrument validasi ahli, instrument tes belajar peserta didik, dan instrument angket respons peserta didik dengan skala Likert dan skala Guttman. Penelitian ini menggunakan analisis kualitatif deskriptif dan kuantitatif. Teknik analisis kualitatif berdasar pada hasil observasi, masukan, dan saran dari ahli sebagai bahan perbaikan dan evaluasi dari produk. Sedangkan teknik analisis kuantitatif dengan merubah data berdasarkan hasil validasi dari ahli, angket respons peserta didik, dan hasil belajar peserta didik dengan merubah data kuantitatif menjadi kualitatif deskriptif dengan menggunakan kriteria skor skala Likert. Berikut tabel kriteria interpretasi:

Tabel. 1 Kriteria Interpretasi

\begin{tabular}{cc}
\hline Presentase & Kriteria \\
\hline $0-20$ & Sangat tidak layak \\
$21-40$ & Tidak layak \\
$41-60$ & Cukup layak \\
$61-80$ & Layak \\
$81-100$ & Sangat layak \\
& p-ISSN 2337-571X $\mid$ e-ISSN 2541-562X \\
& C) 2020 Edunomic: Jurnal Ilmiah Pendidikan Ekonomi \\
Fakultas Keguruan dan Ilmu Pendidikan
\end{tabular}


Sumber: Sugiyono (2018)

\section{Hasil Penelitian}

Pengembangan ini menggunakan model pengembangan ADDIE yang terdapat 5 tahapan, yakni:

1. Analysis, permasalahan yang dihadapi pendidik adalah peserta didik memperoleh nilai yang belum memenuhi KBM yang disebabkan oleh peserta didik merasa tertekan dan tidak tertarik dalam menjalankan proses asesmen dan kurikulum yang digunakan sesuai kurikulum nasional yang berorientasi ke arah pembelajaran internasional

2. Design, merancang media asesmen; (a) merancang soal dan jawaban pada Ms.Word dengan jumlah 10 soal pada setiap materi; (b) merancang tampilan depan yang disesuaikan dengan ukuran layar gawai yang berorientasi portrait, terdapat nama permainan, tingkat sekolah, tingkat kelas, nama pembuat media dan terdapat logo Universitas Negeri Surabaya; (c) merancang petunjuk penggunaan media; (d) merancang menu utama yang berisi menu permainan, menu petunjuk, dan menu deskripsi permainan; (e) merancang kategori permainan yang disesuaikan dengan materi; dan (f) merancang kunci jawaban setelah game berakhir.

3. Development, menciptakan produk yang telah dirancang pada tahap desain pembuatan produk dengan menggunakan aplikasi inventor, setelah media selesai diproduksi, selanjutnya dilaksanakan proses telaah dan validasi oleh ahli asesmen, ahli bahasa dan ahli media sehingga produk layak untuk di uji cobakan.

4. Implementation, melaksanakan uji coba secara nyata yatu ruang kelas dengan tujuan untuk mengetahui kepraktsan dan keefektifan media asesmen Word Search Puzzle.

5. Evaluation, karena keterbatasan waktu maka proses evaluasi dilaksanakan berdasarkan hasil telaah yang berupa kritik, saran dan masukan oleh ahli yang digunakan sebagai pedoman untuk perbaikan produk.

Berikut gambar media asesmen Word Search Puzzle di platform android:

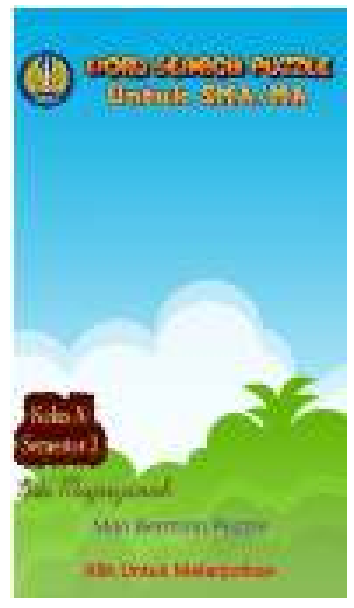

Gambar.3 Tampilan

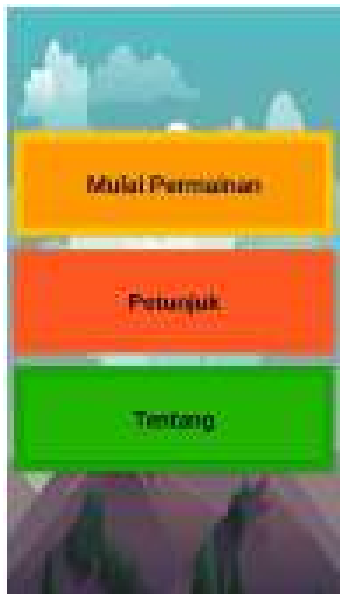

Gambar.4 Tampilan

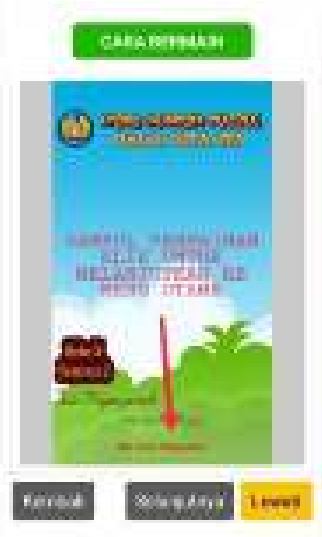

Gambar.5 Petunjuk

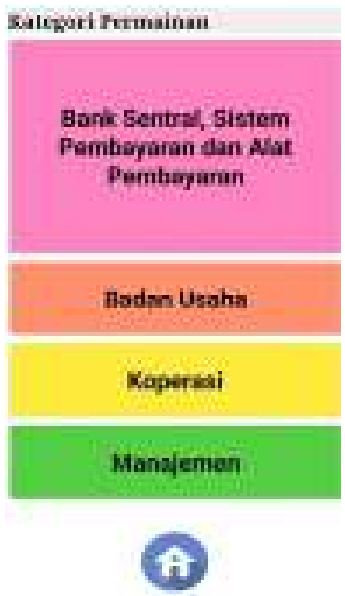

Gambar.6 Kategori

p-ISSN 2337-571X | e-ISSN 2541-562X

(C) 2020 Edunomic: Jurnal Ilmiah Pendidikan Ekonomi Fakultas Keguruan dan Ilmu Pendidikan 
Depan Menu Utama Permainan $\quad$ Permainan

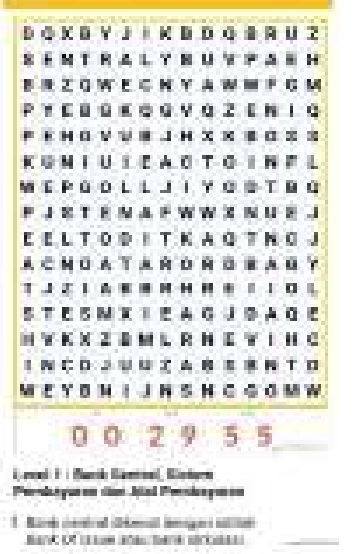

Gambar.7 Tampilan kotak jawaban

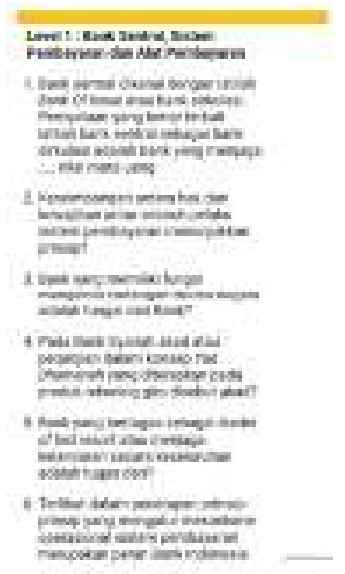

Gambar.8 Tampilan Soal

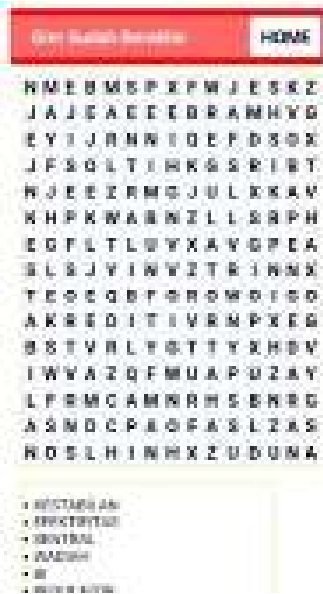

Gambar.9 Tampilan Permainan Brakhir

\section{Kelayakan Media Asesmen Word Search Puzzle di Platform Android pada Mata Pelajaran Ekonomi Kelas X IPS}

Kelayakan media asesmen Word Search Puzzle berdasarkan hasil validasi oleh ahli asesmen, ahli bahasa, dan ahli media. Sebelum dilaksanakan validasi terlebih dahulu dilakukan telaah pada pengembangan media yang memperoleh kritik, masukan, dan saran untuk penyempurnaan sampai media dinyatakan layak untuk dipakai dalam pembelajaran. Setelah proses telaah selesai selanjutnya dilakukan validasi oleh ahli. Berikut hasil validasi dari ahli:

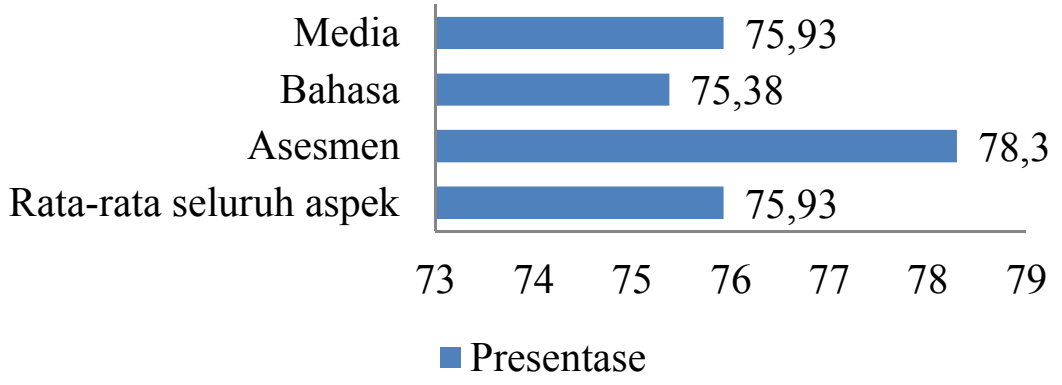

Gambar 10. Diagram Validitas Media Asesmen Word Search Puzzle

Berdasarkan diagram diatas hasil validasi kelayakan media asesmen Word Search Puzzle rata-rata keseluruhan aspek memperoleh presentase $75,93 \%$ yang dikategorikan layak. Hasil validasi ahli dapat dinyatakan valid apabila penilaian kevalidan memiliki presentase $\geq 61 \%$ (Sugiyono, 2018).

Hasil validasi ahli asesmen memperoleh hasil rata-rata presentase $78,3 \%$ yang dikategorikan layak. Menurut Arifin, (2018) asesmen dapat dinyatakan layak apabila 
melengkapi syarat dari aspek kevalidan, keterandalan, dan aspek kepraktisan. Hasil validasi dapat dinyatakan valid apabila penilaian kevalidan memiliki presentase $\geq 61 \%$ (Sugiyono, 2018). Selanjutnya hasil validasi ahli bahasa memperoleh hasil rata-rata presentase $75,38 \%$ yang dikategorikan layak. Menurut Ramadhan (2016) kebahasaan dapat dikatakan valid apabila melengkapi syarat dari aspek kevalidan dan memuat pokok bahasa yang lengkap. Hasil validasi dapat dinyatakan valid apabila penilaian kevalidan memiliki presentase $\geq 61 \%$ Sugiyono(2018).

Kemudian hasil validasi ahli media memperoleh hasil rata-rata presentase $74,11 \%$ yang dikategorikan layak. Media dinyatakan layak apabila telah melengkapi aspek kevalidan, aspek kepraktisan, dan aspek keefektifan Nieveen (Fatmawati, 2016). Hasil validasi ahli dapat dinyatakan valid apabila syarat dari keseluruhan aspek penilaian kevalidan memiliki rata-rata presentase $\geq 61 \%$ (Sugiyono, 2018).

\section{Kepraktisan Media Asesmen Word Search Puzzle di Platform Android pada Mata Pelajaran Ekonomi Kelas X IPS}

Hasil respons dari peserta didik diperoleh selepas melaksanakan uji coba terbatas dengan menyebar angket kepada 28 peserta didik.Angket memiliki 10 pertanyaan yang terdiri dari aspek petunjuk media, isi media, dan penggunaan media.Peserta didik memilih jawaban yang telah disediakan yakni "YA" dan "TIDAK" dimana jawaban "YA" memperoleh skor 1 dan jawaban "TIDAK" memperoleh skor 0. Berikut hasil respons peserta didik:

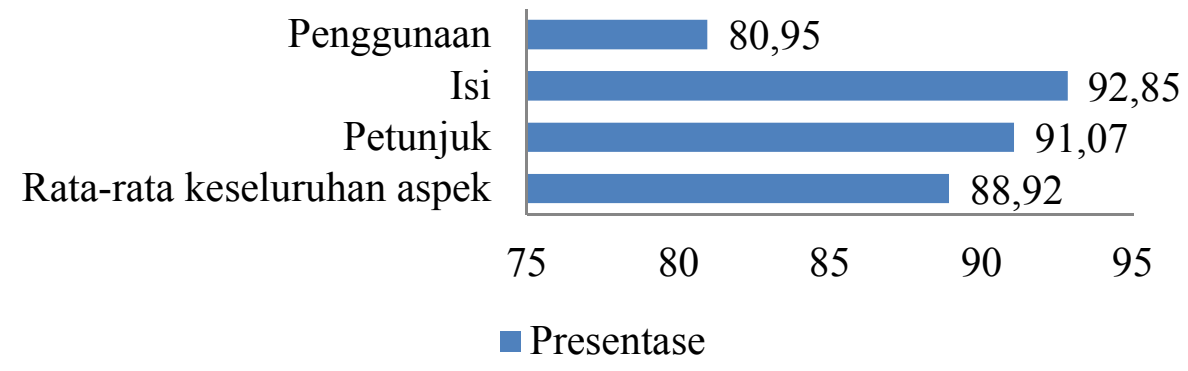

Gambar 11. Diagram Respons Peserta Didik

Berdasarkan diagram diatas respons peserta didik memperoleh hasil rata-rata keseluruhan aspek 88,92\% yang berkategori sangat layak. Apek isi media memperoleh ratarata tertinggi, karena peserta didik tertarik dengan tampilan maupun isi dari media yang dapat mengabungkan pembelajaran dengan permainan. Selaras dengan hasil penelitian Sholeh, Fakiah, \& Adi P.(2018) menunjukkan bahwa aplikasi permainan Word Search Puzzle dapat digunakan sebagai alternatif untuk bermain sambil belajar. Media dapat dikatakan layak apabila sudah memenuhi aspek kevalidan, aspek kepraktisan, dan aspek keefektifan Nieveen (Fatmawati, 2016). Hasil validasi dapat dinyatakan valid apabila memiliki presentase $\geq 61 \%$ (Sugiyono, 2018).

\section{Keefektifan Media Asesmen Word Search Puzzle di Platform Android pada Mata Pelajaran Ekonomi Kelas X IPS}

Hasil belajar peserta didik diperoleh setelah melakukan uji coba terbatas yang dilaksanakan kepada 28 peserta didik kelas X IPS 2 SMA Labschool UNESA untuk melihat 
keefektifan penggunaan media asesmen. Hasil belajar peserta didik dinyatakan tuntas apabila mendapat skor $\geq 75$ sesuai dengan KBM yang berlaku di sekolah. Berikut hasil belajar peserta didik sebelum dan sesudah menggunakan media asesmen Word Search Puzzle:

Tabel 2. Hasil Tes Belajar Peserta Didik

\begin{tabular}{|c|c|c|}
\hline No & Nilai Pretest & Nilai Posttest \\
\hline 1 & 78 & 100 \\
\hline 2 & 68 & 90 \\
\hline 3 & 45 & 80 \\
\hline 4 & 65 & 100 \\
\hline 5 & 85 & 100 \\
\hline 6 & 78 & 90 \\
\hline 7 & 90 & 100 \\
\hline 8 & 65 & 80 \\
\hline 9 & 80 & 80 \\
\hline 10 & 90 & 100 \\
\hline 11 & 58 & 100 \\
\hline 12 & 78 & 100 \\
\hline 13 & 85 & 100 \\
\hline 14 & 65 & 100 \\
\hline 15 & 80 & 100 \\
\hline 16 & 65 & 80 \\
\hline 17 & 70 & 100 \\
\hline 18 & 55 & 80 \\
\hline 19 & 85 & 100 \\
\hline 20 & 75 & 100 \\
\hline 21 & 60 & 90 \\
\hline 22 & 80 & 90 \\
\hline 23 & 55 & 80 \\
\hline 24 & 60 & 100 \\
\hline 25 & 90 & 90 \\
\hline 26 & 75 & 80 \\
\hline 27 & 60 & 80 \\
\hline 28 & 75 & 90 \\
\hline Presentase Ketuntasan & $54 \%$ & $100 \%$ \\
\hline
\end{tabular}

Sumber: Diolah peneliti (2020)

Melihat hasil belajar peserta didik kelas X IPS 2 SMA Labschool UNESA, menunjukkan hasil bahwa sebelum menggunakan media asesmen Word Search Puzzle memperoleh ketuntasan klasikal dengan presentase 54\% dan saat pengukuran hasil belajar dengan menggunakan media asesmen Word Search Puzzle dari 28 peserta didik seluruhnya memperoleh skor memenuhi KBM dengan presentase ketuntasan klasikal sebesar $100 \%$ 
yang dikategorikan sangat layak. Tes hasil belajar dapat dinyatakan tuntas apabila ketuntasan klasikal menunjukkan hasil $\geq 61 \%$ (Riduwan, 2015).

\section{Pembahasan}

1. Media asesmen Word Search Puzzle di platform android yang dikembangkan dinyatakan layak sesuai dengan kriteria kelayakan dari segi aspek kevalidan, aspek keterandalan, dan aspek kepraktisan (Z. Arifin, 2013), hal ini ditunjukan oleh hasil telaah dan validasi oleh ahli asesmen, ahli bahasa, dan ahli media yang memperoleh presentase hasil melebihi standart kelayakan. Presentase hasil kelayakan dapat dikatakan valid apabila memperoleh hasil $\geq 61 \%$ (Sugiyono, 2018). Dimulai dari hasil validasi asesmen memperoleh presentase sebesar 78,3\% yang dikategorikan layak, dimana soal pada media asesmen sudah sesuai dengan indikator yang disajikan sesuai dengan materi, soal sesuai dengan kondisi peserta didik, dan media dapat menaikkan hasil belajar peserta didik. Selanjutnya validasi bahasa memperoleh presentase sebesar 75,38\% yang dikategorikan layak. Kebahasaan dapat dikatakan valid apabila melengkapi syarat dari aspek kevalidan dan memuat pokok bahasa yang lengkap (Ramadhan, 2016). Dimana media asesmen sudah menggunakan bahasa yang disesuaikan dengan Kamus Besar Bahasa Indonesia (KBBI), penggunaan istilah yang sudah disesuaikan dengan susunan Ejaan Yang Disempurnakan (EYD) dan istilah dalam ekonomi, dan menggunakan bahasa yang mudah dimengerti oleh peserta didik. Yang terakhir validasi media memperoleh presentase sebesar $74,11 \%$ yang dikategorikan layak karena telah melengkapi aspek kevalidan, kepraktisan, dan keefektifan Nieveen (Fatmawati, 2016). Dimana media asesmen yang dikembangkan menggunakan tampilan yang dapat meningkatkan minat peserta didik, memiliki petunjuk media yang mudah dipahami dan media mudah untuk digunakan dalam proses asesmen. Rata-rata keseluruhan validasi sebesar 75,93\% yang dikategorikan layak karena sudah memenuhi kriteria kelayakan dari BNSP (2014). Penelitian ini sesuai dengan penelitian yang dilaksanakan oleh Hermawaty, Krisdiawan, \& Andriyat(2019) dengan menggunakan media pembelajaran Word Search Puzzle dapat meningkatkan minat peserta didik untuk belajar sambil bermain karena pembelajaran dikemas dalam bentuk game yang menarik, selanjutnya pada penelitian Ratnaningsih(2010) permainan Word Search Puzzle dapat meningkatkan penguasaan kosa kata sehingga meningkatkan hasil belajar peserta didik.

2. Hasil respons peserta didik memperoleh presentase sebesar $88,92 \%$ yang dikategorikan sangat layak. Media dapat dinyatakan layak apabila sudah melengkapi aspek kevalidan, aspek kepraktisan, dan aspek keefektifan Nieveen (Fatmawati, 2016). Media dapat dikatakan praktis apabila hasil respons pesrta didik memperoleh skor hasil rata-rata presentase $\geq 61 \%$ (Yenti, 2014). Aspek isi media memperoleh rata-rata tertinggi, dimana peserta didik tertarik dengan tampilan dan isi dari media yang mengabungkan permainan dengan proses asesmen sehingga proses asesmen dirasa lebih menyenangkan dan tidak merasa terbebani, isi media disesuaikan dengan kriteria kelayakan dari BNSP(2014). Sesuai dengan hasil penelitianKhomsoh \& Gregorius (2017) apabila pembelajaran telah berlalu maka peserta didik merasa kesulitan dalam mengingat dan memahami materi yang telah disampaikan sehingga dibutuhkan media asesmen yang menyengkan agar mengurangi beban fikiran peserta didik yang dapat berpengaruh pada hasil belajar. Kemudian penelitian 
Paramita(2018) menunjukkan hasil bahwa media pembelajaran Word Search Puzzle dapat meningkatkan keaktifan dan hasil belajar peserta didik. Selanjutnya penelitian yang dilaksanakan Wati(2018) menunjukkan hasil Word Search Puzzle dapat meningkatkan motivasi belajar peserta didik yang berpengaruh terhadap hasil belajar peserta didik yang mengalami peningkatan.

3. Media asesmen Word Search Puzzle di platform android dapat meningkatkan hasil belajar peserta didik kelas X IPS 2 SMA Labschool UNESA. Hal tersebut ditunjukan oleh hasil belajar peserta didik yang mengalami peningkatan dimana sebelum menggunakan media hasil ketuntasan klasikal sebesar 54\% dan setelah menggunakan media asesmen Word Search Puzzle hasil ketutasan klasikal sebesar 100\%, karena peserta didik merasa senang saat melaksanakan proses asesmen. Penelitian ini selaras dengan hasil penelitian yang dilaksanakan oleh Wahyuni H (2018) dengan menggunakan media pembelajar Word Search Puzzle dapat meningkatkan hasil belajar peserta didik dengan presentase $100 \%$, kemudian pada penelitian Al-Furqon (2017) penggunaan permainan Word Search Puzzle memberikan dampak positif pada peserta didik dalam meningkatkan penguasaan kosa kata. Penggunaan Word Search Puzzle menunjukkan peningkatan hasil belajar yang signifikan yang sebelumnya hanya $54 \%$ menjadi $100 \%$ peserta didik yang memperoleh nilai diatas KBM karena peserta didik tidak merasa tertekan dan dapat dengan mudah menemukan jawaban dari soal yang diberikan. Dengan mengabungkan permainan Word Search Puzzle pada proses asesmen dapat membuat peserta didik lebih aktif, cekatan, dan berpikir lebih cepat untuk menemukan jawaban sehingga hasil belajar dapat meningkat, selaras dengan penelitian Purnomo \& Hermawan (2016) semakin panjang karakter pada kata yang dicari maka waktu yang dibutuhkan untuk menemukan kata akan semakin lama dan menyebabkan peserta didik merasa terpacu untuk berfikir lebih cepat sehingga dapat menemukan jawaban lebih cepat dan memperoleh hasil yang baik, serta Murwiyati (2015) menunjukkan hasil belajar peserta didik mengalami peningkatan dengan penggunaan media Word Search Puzzle dalam asesmen.

\section{Simpulan}

Berdasarkan hasil penelitian yang telah dilaksanakan dapat ditarik kesimpulan bahwa: (1) pengembangan media asesmen Word Search Puzzle dinyatakan layak, berdasarkan hasil validasi dengan rata-rata presentase 75,93\%; (2) media Word Search Puzzle dinilai praktis dipakai dalam pembelajaran karena mampu meningkatkan ketertarikan peserta didik berdasarkan respons peserta didik yang mendapat rata-rata presentase 88,92\%; dan (3) media asesmen Word Search Puzzle efektif digunakan untuk mengukur hasil belajar peserta didik dengan hasil akhir 100\% dinyatakan lulus ketuntasan klasikal.

\section{Referensi}

Al-Furqon, A. S. (2017). the Effect of Word Search Puzzle Game in Teaching Vocabulary To the First Gradestudents of Smpn 3 Proppo. Wacana Didaktika, 5(02), 101.

https://doi.org/10.31102/wacanadidaktika.v5i02.25

Aminudin, N., Huda, M., Hehsan, A., Ripin, M. N., Haron, Z., Junaidi, J., ... Fauzi, A. N. (2018). Application program learning based on android for students experiences.

\footnotetext{
p-ISSN 2337-571X | e-ISSN 2541-562X

(C) 2020 Edunomic: Jurnal Ilmiah Pendidikan Ekonomi Fakultas Keguruan dan Ilmu Pendidikan
} 
International Journal of Engineering \& Technology, 7(2.27), 295.

https://doi.org/10.14419/ijet.v7i2.27.11574

Arifin, R. (2018). Survei Minat dan Motivasi Siswa Terhadap Mata Pelajaran Penjas Siswa SMA Swasta Kecamatan Panakkukang Kota Makassar.

Arifin, Z. (2013). Evaluasi pembelajaran: Prinsip, Teknik, Prosedur. Bandung: Remaja Rosdakarya.

Bnsp. (2014). Instrumen Penilaian Kelayakan Media Sekolah Menengah Atas/Madarasah Aliyah, $I X(3)$.

Chesy, L. (2018). The Use of Word Search Puzzle To Teach Students' Vocabulary Mastery, (2), 1-10. https://doi.org/10.1051/matecconf/201712107005

Chin, J., Payne, B. R., Fu, W. T., Morrow, D. G., \& Stine-Morrow, E. A. L. (2015). Information Foraging Across the Life Span: Search and Switch in Unknown Patches. Topics in Cognitive Science, 7(3), 428-450. https://doi.org/10.1111/tops.12147

Fatmawati, A. (2016). Pengembangan Perangkat Pembelajaran Konsep Pencemaran Lingkungan Menggunakan Model Pembelajaran Berdasarkan Masalah untuk SMA Kelas X. EduSains, 4(2).

Gargenta, M. (2011). Learning ndroid. (A. Oram \& B. Jepson, Ed.) (first). America: O'Really Media. Diambil dari https://books.google.co.id/books?id=oMYQz4_BW48C\&printsec=frontcover\&hl=id\#v= onepage \&q\&f=false

Hermawaty, D., Krisdiawan, R. A., \& Nurhayati, Y. (2019). Game Edukasi Word Search Puzzle Nama Anak Hewan Dalam Bahasa Sunda Menggunakan Algoritma Linear Congruent Method (LCM) dan Algoritma Knuth Morris Pratt (KMP). Jurnal Nuansa Informatika, 13(2), 24-32.

Khomsoh, R., \& Gregorius, J. (2017). Hasil penelitian menun, 1-11.

Mahendra, J. (2016). Model Pengembangan Media Pembelajaran ADDIE. Grafis Paten. Diambil dari https://grafispaten.wordpress.com/2016/01/02/model-pengembanganmedia-pembelajaran-addie/

Mailawati. (2019). Pengaruh penggunaan media word search puzzle terhadap minat belajar pendidikan kewarganegaraan kelas viii di smpmuhammadiyah 49 medan tahun pembelajaran 2017/2018.

Murwiyati, D. (2015). Pengaruh Penggunaan Media Word Search Puzzle Terhadap Minat Dan Hasil Belajar Pendidikan Kewarganegaraan Siswa Kelas VII di SMP N 4 Wates, (2), 430 .

Nurseto, T. (2011). Membuat Media Pembelajaran yang Menarik. Ekonomi \& pendidikan, $8(1), 19-35$.

Paramita, N. C. (2018). Peningkatan Keaktifan Siswa Melalui Model Kooperatif Tipe TGT 
degan Media Word Search Puzzle dan Crossword Puzzle di Kelas XI MIPA 6 SMA Muhammadiyah 1 Karanganyar Tahun Pelajaran 2018/2019, 4(1), 75-84. https://doi.org/.1037//0033-2909.I26.1.78

Purnomo, A. J., \& Hermawan, G. (2016). Implementasi Algoritma Simplified Memory Bounded A* Untuk Pencarian Kata Pada Permainan Word Search Puzzle. Jurnal Ilmiah Komputer dan Informatika (KOMPUTA), 5(1), 1-10.

Purwati, D., \& Nugroho, A. N. P. (2018). Pengembangan Media Evaluasi Pembelajaran Sejarah Berbasis Google Formulir Di Sma N 1 Prambanan. ISTORIA: Jurnal Pendidikan dan Ilmu Sejarah, 14(1). https://doi.org/10.21831/istoria.v14i1.19398

Raharjo, S. B. (2010). Pendidikan Karakter sebagai Upaya Menciptakan Akhlak Mulia. Jurnal Pendidikan dan Kebudayaan, 16(3), 229-238.

Rahmah, A. (2016). the Effect of Word-Search Puzzle on Vocabulary Size At the Seventh Grade Students of Smp Muhammadiyah Buntok.

Ramadhan, R. G. (2016). Intrumen Penilaian Multimedia Pembelajaran, 137-140.

Ratnaningsih, T. (2010). Penggunaan Evaluasi Word Search Puzzle untuk Meningkatkan Kosa Kata Biologi Siswa pada Pokok Bahasan Zat Additif dan Psikotropika Kelas VIII SMP Negeri 7 Surabarta Tahun Pelajaran 2008/2009.

Riduwan. (2015). Skala Pengukuran Variabel-Variabel Penelitian. Bandung: Alfabeta.

Saidah, I. N. (2015). Pengembangan Media Pembelajaran Berbentuk Permainan Edukasi Akuntansi Cari Kata (ACAK) Dengan Menggunakan Software Abode Flash Cs5 Untuk Pembelajaran Akuntansi Keuangan Kompetensi Dasar Aset Tetap Di Kelas XI Akuntansi SMK YPE Sawunggalih Kutoarjo Tahun A.

Salkind, N. (2013). Behavior Assessment System for Children. Encyclopedia of Measurement and Statistics. https://doi.org/10.4135/9781412952644.n50

Sani, R. A., Manurung, S. R., Suswanto, H., \& Sudiran. (2018). Penelitian Pendidikan (1 ed.). Tangerang: Tira Smart.

Sholeh, M., Fakiah, E., \& Adi P, G. (2018). Rancang Bangun Aplikasi Permainan Adu Cepat Membaca Menggunakan Permainan Multiplayer Word Search Puzzle, 123-135.

Sugiyono. (2018). Metode Penelitian Pendidikan Pendekatan Kuantitatif, Kualitatif, dan $R \& D$ (27 ed.). Bandung: CV Alfabeta.

Tarigas, T. D. (2014). Pengembangan Media Crossword Puzzle Chemistry (Cropchem) Pada Materi Struktur Atom di SMA, 1-12.

Wahyuni H, S. (2018). Pengembangan Media Pembelajaran Word Search Puzzle Pada Kelas X IIS SMA Negeri 16 Surabaya Tahun Pelajaran 2017/2018. Jurnal Pendidikan Ekonomi (JUPE), 6(3), 336-342.

Wati, D. S. (2018). Pengembangan Media Visual Berbasis Word Search Puzzle Untuk Meningkatkan Motivasi Belajar Siswa. 
Wulan, A. R. (2010). 10 Konsep Evaluasi Dan Sitasinya. FMIPA Universitas Pendidikan Indonesia, 1-12.

Yenti, I. N. (2014). Kepraktisan bahan ajar berbasis e-learning untuk mata kuliah kalkulus peubah banyak 1 (KPB 1). Ta'dib, 17(1), 14-24.

Yumarlin, M. (2013). Pengembangan Permainan Ular Tangga Untuk Kuis Mata Pelajaran Sains Sekolah Dasar. Teknik, 3(April 2013), 77.

p-ISSN 2337-571X | e-ISSN 2541-562X 